\title{
MOUNTAIN CHICKADEE IN SOUTHWESTERN SASKATCHEWAN
}

\author{
by Steve A. Mann, Piapot
}

We first noticed a chickadee with a white stripe above the eye feeding at our trays outside the kitchen window, on December 3, 1966. At first we thought it was a freak Blackcapped Chickadee as we could not find any bird similar to it in Roger $T$. Peterson's Field guide to the birds or Richard Pough's Audubon bird guide, but we finally found it in P. A. Taverner's Birds of Western Canada and Chapman and Reed's Color key to North American birds. After that, we were fairly certain that it was not a "freak" but a true specimen of a Mountain Chickadee which had wandered from its regular range. After making inquiries by correspondence of several authorities on birds and their habits we were convinced that it was a first record for Saskatchewan.

The Mountain Chickadee breeds in the mountains of western North America. In southwestern Alberta it has been recorded as a permanent resident in the Jasper, Banff and Waterton Lakes parks. Neither the revised edition of Salt and Wilk's Birds of Alberta (1966) nor W. E. Godfrey's new Birds of Canada (1966) has any record of the Mountain Chickadee wandering farther east on the Prairies than Calgary and Edmonton. Following my report of the Mountain Chickadee at Piapot, Margaret Belcher called my attention to a report of two seen by the Calgary Bird Club on their 1966 Christmas Bird Count, and to another report for the Black Hills in South Dakota published in Audubon Field Notes, 21:50, February, 1967: "A Mountain Chickadee at Rapid City from Nov. 19 to Nov. 30 was the first local record and was 'probably a stray from the Casper Mountains about 250 miles west.'"

"Stripes", as we named the unusual chickadee, could be seen at feed trays around our yard any day from December 3 to the end of March, and then only on odd days thereafter. The last date we saw the chickadee was on April 22.

We had a mild spell on March 15 and 16 when "Stripes" treated us to his song, which was quite different from the spring song of the Blackcapped Chickadee. In was a three-note trill, quite clear and distinct: one that a person used to hearing bird songs and calls would stop and listen to, and investigate to find the bird that was singing. There were only four of us that heard its song, but quite a number came to see the bird at the trays.

We tried to get some snapshots of it through the window, about two feet from the bird, and others out of doors. No one in the district had a camera with a special lens, so all the snaps were taken with an ordinary camera. Of those that we have had developed so far, only one has proven clear enough to tell that it was even a chickadee, but it is to be hoped that we shall still get a picture that would be useful in identifying the bird. Some suggested that I should collect the bird to have a fully supported record for Saskatchewan, but we became too attached to it to consider destroying it. I believe, though, that enough people have come to see it feeding at our trays to establish it as a Mountain Chickadee and not a freak.

\section{COOPERATIVE MIGRATION STUDY}

Contributors to the cooperative migration survey, carried on under the auspices of the U.S. Fish and Wildlife Service, are reminded to send their records by July 15, 1967 to

Mrs. Mary Houston

863 University Drive

Saskatoon, Saskatchewan. 